\title{
СФЕРОКОНИЧЕСКИЕ СОСУДЫ ЦАРЕВСКОГО ГОРОДИЩА ${ }^{1}$
}

\author{
(C) 2021 г. А.P. Нуретдинова
}

Сфероконические сосуды - особая категория посуды полифункционального назначения, часто встречающаяся на средневековых поволжских памятниках археологии. В статье рассматриваются основные типы сфероконусов Царевского городища, хранящиеся в Археологическом музее Казанского федерального университета, Волгоградском областном краеведческом музее, Государственном Эрмитаже, а также форма из камня для изготовления конусообразных сосудов. Обзор этих изделий в контексте изучения сфероконических сосудов с других золотоордынских памятников позволяет установить особенности их бытования на нижневолжских памятниках.

Ключевые слова: археология, сфероконические сосуды, керамика, каменная форма, Золотая Орда, Царевское городище, XIV век, сотовый орнамент.

\section{SPHERO-CONICAL VESSELS FROM TSAREVSKOYE SETTLEMENT ${ }^{2}$}

\section{A.R. Nuretdinova}

Sphero-conical vessels are a special category of multifunctional tableware often discovered at medieval Volga archaeological sites. The paper examines the main types of sphero-conical vessels found at Tsarevskoye settlement, deposited in the Archaeological Museum of Kazan Federal University, Volgograd Regional Museum of Local Lore and the State Hermitage, as well as a stone mold for making cone-shaped vessels. A review of these items in the context of the study of sphero-conical vessels from other Golden Horde sites makes it possible to establish the peculiarities of their existence at Lower Volga sites.

Keywords: archaeology, sphero-conical vessels, pottery, stone mold, Golden Horde, Tsarevskoye settlement, $14^{\text {th }}$ century, honeycomb ornament.

Сфероконические сосуды являются достаточно часто встречающимся археологическим материалом на территории Золотой Орды, что говорит об их доступности и широком использовании в быту и ремесле. В отечественной литературе много публикаций, посвященных сфероконусам как отдельных золотоордынских центров: Старый Орхей и Костешты (Абызова, 1982; Полевой, 1969), Белгород на Днестре (Кравченко, 1986), Азак (Масловский, 2006), Укек (Недашковский, 2000), Маджар (Ртвеладзе, 1974), Красноярское и Селитренное городища (Пигарев, 1994), так и в целом с территории Золотой Орды (Федоров-Давыдов, 1994, с. 141-142; Волков, 2004).

Настоящая статья представляет анализ находок сфероконических сосудов с территории Царевского городища (Сарай ал Джедид или Новый Сарай), основанного во второй половине 30-х годов XIV века и просуществовавшего до 1395 года. Руины города обна- ружены в Волгоградской области на берегу речки Ахтубы, притока Волги.

Самые ранние находки сфероконических сосудов с территории Царевского городища хранятся в Государственном Эрмитаже. Они происходят из раскопок титулярного советника А.В. Терещенко, «известного своими занятиями по части истории и древностей, который и отправлен на место предположенных розысканий, с нужными наставлениями и пособиями» (Древние памятники..., 1843, с. 427), который по приказу министра внутренних дел Л.А. Перовского был направлен для изучения руин золотоордынского города. Работы проходили с 1843 г. по 1851 г. В результате был накоплен большой объем вещественных источников, в том числе керамические изделия. Особенно интересны нам находки сфероконических сосудов и каменной формы (рис. 1-3). Стоит отметить, что в массе своей сосуды хорошей сохранности, что может свидетельствовать о выборке более презен-

1 Исследование подготовлено при поддержке Российского фонда фундаментальных исследований (РФФИ), проект № 20-09-00240 «Царевское городище: изучение материалов раскопок 1961-1968 гг. из фондов Археологического музея Казанского федерального университета и Государственного исторического музея».

The study was prepared with the support of the Russian Foundation for Basic Research (RFBR), project No. 2009-00240 "Tsarevskoye settlement: study of excavation materials from 1961-1968 from the funds of the Archaeological Museum of Kazan Federal University and the State Historical Museum". 
тативных форм для дальнейшего музейного хранения. Всего из собрания А.В. Терещенко был изучен 21 сосуд разной степени сохранности.

С 1959 г. начались стационарные раскопки Царевского городища Нижневолжской археологической экспедицией под руководством Г.А. Федорова-Давыдова (Федоров-Давыдов, 1964; Федоров-Давыдов и др., 1970). На сегодняшний день материалы раскопок хранятся в Государственном Историческом музее, Волгоградском областном краеведческом музее и Археологическом музее Казанского (Приволжского) федерального университета. Из последних двух научных центров было изучено 5 сосудов во фрагментах и обломках.

Таким образом, на сегодняшний день выборка сфероконических сосудов с Царевского городища составила 26 экземпляров. Условно их можно поделить на 2 блока: 1 серые и желтые разных оттенков и 2 - красные.

Серые и желтые сфероконусы составляют большинство на памятнике - 22 экз.

Среди серых наиболее многочисленны сосуды темно-серые с массивной головкой с валиком и коническим дном, с «сотовым» или «семечковидным» орнаментом - подтип 2.I.3 по типологии средневолжских сфероконических сосудов (Нуретдинова, 2011, с. 155, рис. 3,3). Валик в основании головки является переходом шляпки в тулово (без горла). Они хорошо узнаваемы благодаря и форме, и броскому орнаменту.

Украшение сосудов «сотовым» («семечковидным») орнаментом появилось в предмонгольское время на Ближнем Востоке, в частности в иорданском Аджлуне (Nicolle, 2016, p. 167), в Иране X-XII вв. (Fehervari, 2000, p. 210, № 275), а затем стало очень популярным на территории Золотой Орды: в Костештах и Старом Орхее (Кравченко, 1986, с. 61, рис. 24, 1-5; Полевой, 1969, с. 135), Болгаре, Старокуйбышевском городище (Нуретдинова, 2011, с. 155), Укеке (Недашковский, 2000, c. 100 , рис. 26,1$)$, Красном Яре и Селитренном городище (Пигарев, 1994, с. 212-213, рис. 1, 9,12), Азаке (Масловский, 2006, с. 418, рис. 44, 1-3), Маджаре (Ртвеладзе, 1974, c. 280-284), Сарайчике (Самашев, Кузнецова, 2008, с. 138). Следует отметить, что ранее в Египте сосуды с «сотовым» орнаментом рассматривались как фатимидско-сельджукские (Скэнлон, 1981, с. 287, рис. 4), современные исследователи относят их к мамлюкскому периоду (Monchamp, 2016, p. 203; Whitcomb, 2016, p. 181).

Можно выделить несколько вариантов орнамента:

Варианm 1 - сосуды, тулово которых украшено вытянутыми «овалами» или «арками», пространство между ними, как правило, было заполнено т. н. «сотовым», «семечковидным», «кольчужным» штампом, сами «овалы» также могли быть заполнены этим орнаментом (рис. 1: 4, 6, 8; 2: 4-6; 3: 4, 6; 4: 2, 5). Размеры: высота (H) варьирует от 10,5 до 14 см, диаметр тулова (D) - 9,1-10,3 см, толщина дна (T) 2,7-3,5 см, высота шляпки (һшл) - 2,6-3 cм, диаметр шляпки (dшл) - 3,8-4,1 см, диаметр отверстия (дотв) - 0,6-0,7 см, толщина стенки (t) - 1,9-2,2 см. Количество «арок» варьирует от 7 до 9. Особо следует отметить сосуд с чередующимися 8 маленькими и 8 большими овалами (рис. 2: 4). Интересен факт наличия на некоторых экземплярах штампованных цветков на плечиках, количество которых один (табл. 1: 4, 7, 8) или три (табл. 1: 2). Каково назначение этих цветков на сегодняшний день неясно и требует дальнейшего изучения. Возможно, это пометка о содержимом или месте изготовления. Схожие штампованные узоры на плечиках сфероконусов известны также на Селитренном городище (Нуретдинова, 2018, с. 17, рис. 2, 1), в Костешках и Старом Орхее (Абызова, 1982, с. 172, рис. 1, 5, 7).

Аналогии данным сосудам встречены среди материалов Старого Орхея и Костешт (Абызова, 1982, рис. 1, 7); Маджара (Ртвеладзе, 1974, с. 281 , рис. 1,10$)$, Хорезма (Волков, 2004 , с. 159, № 1), Ферганской области (Нуретдинова, 2018 , с. 31 , рис. $8,38,41$ ).

Всего с Царевского городища происходит 11 экз., из них 8 - из раскопок А.В. Терещенко (ГЭ), 2 - в фондах Археологического музея КФУ, 1 - в фондах Волгоградского областного краеведческого музея (табл. 1).

Вариант 2 (5 экз; табл. 2) - сосуды, тулово которых украшено резными линиями, пространство между которыми заполнено «сотовым» орнаментом. Как правило, это были вертикальные двойные линии (рис. 1: 7; 4: 4), но могли быть и более сложные зигзагообразные и пересекающиеся двойные линии (рис. 2: 3). Размеры: $\mathrm{H}-12-13,8$ см, D - 9,3-9,7 см (T - 3-4 см, һшл - 2,5-3 см, dшл $4,2-4,8$ см, dотв - 0,7-0,9 см. На одном из сосудов (рис. 1:2) имеется оттиснутая надпись на арабском «ас Салих», что в переводе - «Благочестивый» (Михальченко, 1974, с. 48). 
Таблица 1. Сфероконусы с «сотовым» орнаментом. Вариант 1

Table 1. Spheroconuses with a "honeycomb" ornament. Variant 1

\begin{tabular}{|c|c|c|c|c|}
\hline $\begin{array}{c}\text { № } \\
\Pi / \Pi\end{array}$ & $\begin{array}{l}\text { Место хранения, } \\
\text { Шифр }\end{array}$ & Размеры, см & Иллюстрация & Примечание \\
\hline 1 & ГЭ, Сар-316 & $\begin{array}{c}\mathrm{H}=11,8, \mathrm{D}=10,3, \mathrm{t}=2,2, \mathrm{hшл=}=3,1, \\
\mathrm{~d} \text { шл }=4,1, \text { dотв }=0,7\end{array}$ & Рис. 1,4 & 9 арок; высота неполная \\
\hline 2 & ГЭ, Сар-385 & $\begin{array}{c}\mathrm{H}=14, \mathrm{D}=9,3, \mathrm{~T}=2,7, \mathrm{hшл=3,} \\
\text { dшл=4 }\end{array}$ & Рис. 1,6 & $\begin{array}{c}8 \text { арок; штампованный } 3 \text { цветка на } \\
\text { плечиках; след от подставки на дне? }\end{array}$ \\
\hline 3 & ГЭ, Сар-387 & $\begin{array}{c}\mathrm{H}=14,5, \mathrm{D}=10,7, \mathrm{~T}=3, \text { Һшл=3,2, } \\
\mathrm{dшл}=4,1, \text { dотв }=0,7\end{array}$ & Рис. 1,8 & 8 арок \\
\hline 4 & ГЭ, Сар-602 & $\begin{array}{c}\mathrm{H}=14, \mathrm{D}=9,4, \mathrm{~T}=3,5, \mathrm{~h} ш л=3, \\
\mathrm{~d}=\mathbf{m}=4, \text { dотв }=0,7\end{array}$ & Рис. 2,4 & $\begin{array}{c}8 \text { больших и } 8 \text { малых арок; } \\
\text { штампованный цветок на плечиках }\end{array}$ \\
\hline 5 & ГЭ, Сар-603 & 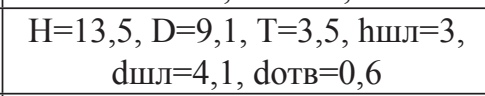 & Рис. 2,5 & 9 арок, растительный орнамент \\
\hline 6 & ГЭ, Сар-604 & $\begin{array}{c}\mathrm{H}=13,2, \mathrm{D}=9,1, \mathrm{~T}=2,7, \mathrm{~h} \text { шл=2,6, } \\
\text { dшл }=3,8, \text { dотв }=0,6\end{array}$ & Рис. 2,6 & 7 арок \\
\hline 7 & ГЭ, Сар-608 & $\mathrm{H}=8,5, \mathrm{D}=9,5$ & Рис. 3,4 & $\begin{array}{c}8 \text { арок; штампованный цветок на } \\
\text { плечиках; шляпка отбита }\end{array}$ \\
\hline 8 & $\Gamma Э$, Сap-610 & $\begin{array}{c}\mathrm{H}=10,5, \mathrm{D}=9,2, \mathrm{t}=1,55, \mathrm{hшл=}=2,8, \\
\mathrm{dшл}=3,8, \text { dотв }=0,6\end{array}$ & Рис. 3,6 & $\begin{array}{c}7 \text { арок; штампованный цветок на } \\
\text { плечиках }\end{array}$ \\
\hline 9 & $\begin{array}{c}\text { АМ КФУ, АКУ- } \\
356 / 18 \\
\end{array}$ & $4,5 \times 5,2 \times 1,9$ & Рис. 4,2 & Цг-1966г., Р. 2, яма 6, № 1768 \\
\hline 10 & $\begin{array}{c}\text { АМ КФУ, АКУ- } \\
356 / 46\end{array}$ & $7 \times 5,15 \times 2,2$ & Рис. 4,3 & Цг-1966 г., Р. 2 \\
\hline 11 & BOKM & - & Рис. 4,5 & $\begin{array}{c}\text { Цг-1962 г., подъемный материал, } \\
\text { № } 41 \\
\end{array}$ \\
\hline
\end{tabular}

Таблииа 2. Сфероконусы с «сотовым» орнаментом. Вариант 2

Table 2. Spheroconuses with a "honeycomb" ornament. Variant 2

\begin{tabular}{|c|c|c|c|c|}
\hline № п/п & Шифр & Размеры, см & Иллюстрация & Примечание \\
\hline 1 & Cap-304 & $\mathrm{H}=12,2, \mathrm{D}=9,6$ & Рис. 1,2 & имеется надпись \\
\hline 2 & Cap-315 & $\begin{array}{c}\mathrm{H}=13,8, \mathrm{D}=9,3, \mathrm{~T}=3, \mathrm{hшл}=3, \\
\text { dшл=4,2, дотв=0,7cм }\end{array}$ & - & 3 цветка на плечиках \\
\hline 3 & Cap-386 & 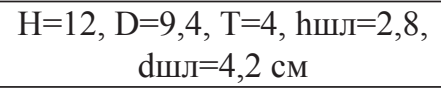 & Рис. 1,7 & коричневая глазурь \\
\hline 4 & Cap-601 & $\begin{array}{c}\mathrm{H}=12,8, \mathrm{D}=9,7, \mathrm{~T}=3,6, \\
\text { Һшл}=2,5, \text { дшл=4,8, дотв=0,9 }\end{array}$ & Рис. 2,3 & \\
\hline 5 & BOKM & & Рис. 4,4 & Цг-64 г., Р. IV, шт. 3, уч. 34 \\
\hline
\end{tabular}

Ближайшие аналогии найдены в материалах Старого Орхея и Костешт (Абызова, 1982, рис. 1,6; Полевой, 1969, с. 135, табл. XXVIII, 2), Белгорода на Днестре (Кравченко, 1986, рис. 24, 2-5,6), золотоордынских памятников Северной Добруджи (Румыния) (Stănică, Szmoniewski, 2016, c. 337, fig. 15; fig. 19), Маджара (Ртвеладзе, 1974, с. 281, рис. 1,9), Красноярского городища (Пигарев, 1994 , с. 213 , рис. 1,9), Укека (Недашковский, 2000 , с. 100 , рис. $26,3,8$; Виноградов, 1922, c. 111, табл. №6, 81), Болгара (Виноградов, 1922, с. 111, табл. № 6,79-80), Баальбека (Vezzoli, 2016, p. 223, fig. 6,1), Бания' са (Изра- иль) (Sharvit, 2007, p. 105-106), Египта (Виноградов, 1922, с. 111, табл. № 6, 82).

Всего 5 сосудов имеют подобный орнамент, из которых 1 хранится в фондах Волгоградского областного краеведческого музея, остальные - в фондах Государственного Эрмитажа (табл. 2).

Вариант 3 (1 экз.) - сосуд серого цвета, тулово которого украшено подтреугольными фигурами из «сотового» орнамента (рис. 3: 1), происходит из коллекции А.В. Терещенко. Размеры: Н - 11,8 см, D - 9 см, Т - 1,8 см, һшл -3 см, dшл - 4,2 см. Шляпка частично отбита. Подобные сосуды встречены среди мате- 

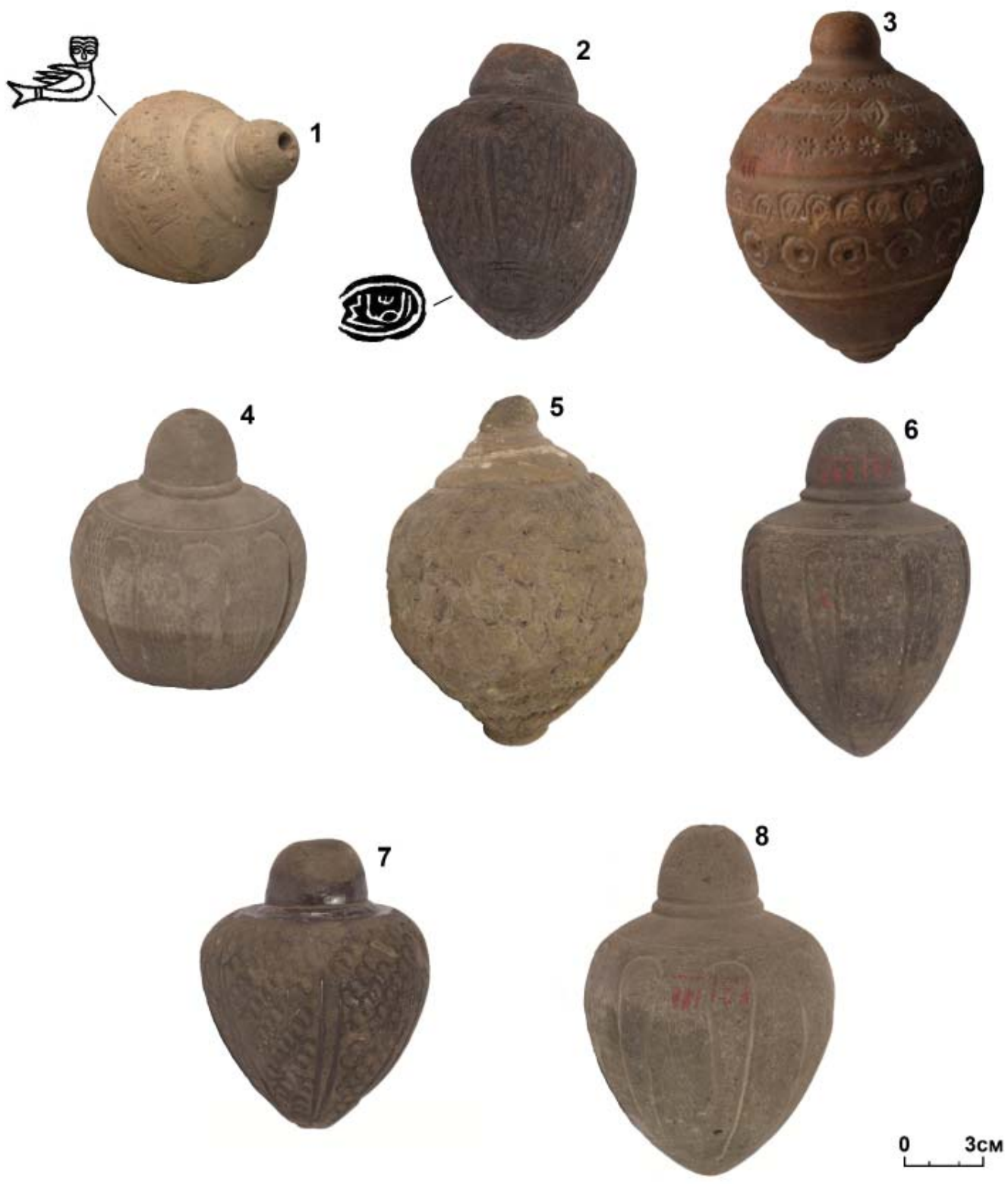

Рис. 1. Сфероконические сосуды из раскопок А.В. Терещенко, Государственный Эрмитаж. Фото из Государственного каталога Музейного фонда Российской Федерации

Fig. 1. Sphero-conical vessels from the excavations of A.V. Tereshchenko, State Hermitage.

Photo from the State Catalog of the Museum Fund of the Russian Federation

риалов Селитренного городища (Пигарев, 1994, с. 213, рис. 1,12), Укека, Болгара (Виноградов, 1922, с. 111, табл. № 6, 77), Белгорода на Днестре (Кравченко, 1986, рис. 24, 1; Полевой, 1969 , с. 135 , табл. XXVIII,1), золотоордынских памятников Северной Добруджи (Румыния) (Mănucu-Adameşteanu, 1984, c. 723 , pl. 8, 5, 6), Бания' са (Израиль) (Sharvit, 2007, p. 105-106), Хорезма (Волков, 2004, c. 159, № 2), Баальбека (Vezzoli, 2016, p. 223, fig. 6,2), Египта (Виноградов, 1922, с. 111, табл. № 6, 77), в коллекции Л.О. Сиклера из Среднего Поволжья (Нуретдинова, 2018, с. 95 , рис. 43,8$)$.
Остальные серые и желтые сфероконические сосуды представлены единично.

Один фрагмент сосуда (рис. 2: 2; Сар-479) серого цвета, эллипсоидной формы с расширенным в верхней трети туловом, со ступенчатым оформлением верхней части и штампованным орнаментом на тулове схож со сфероконусами подтипа 2.I.13 по типологии средневолжских сфероконических сосудов (Нуретдинова, 2011, рис. 3,13). Размеры: $10,5 \times 7,7 \times 0,9$ см. Ближайшие аналогии можно встретить среди материалов Болгара (Нуретдинова, 2011, с. 155) и Укека (Недашковский, 2000 , рис. 26). 

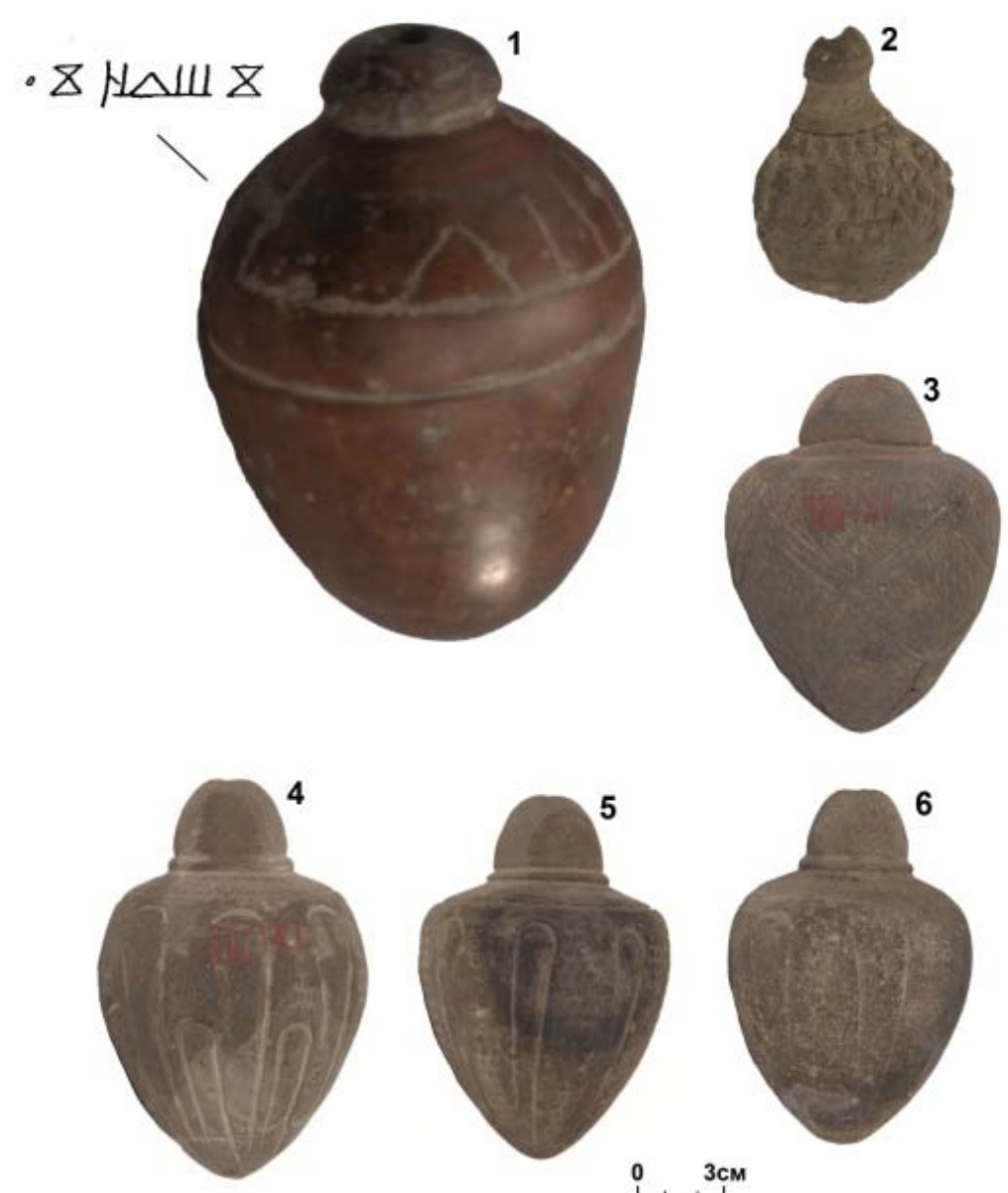

Рис. 2. Сфероконические сосуды из раскопок А.В. Терещенко, Государственный Эрмитаж. Фото из Государственного каталога Музейного фонда Российской Федерации

Fig. 2. Sphero-conical vessels from the excavations of A.V. Tereshchenko, State Hermitage. Photo from the State Catalog of the Museum Fund of the Russian Federation

Следующий сосуд из раскопок А.В. Терещенко серо-желтого цвета эллипсоидной формы с расширенным в верхней трети туловом, с шайбообразной головкой и уплощенным дном (рис. 1, 5; Сар-384). Размеры: Н 14,8 см, D - 10,7 см, T - 4,5 см, дшл - 2,8 см. Данные сосуды легко узнаваемы по богатому, выполненному штампом орнаменту по всей поверхности тулова и характеру завершения сосуда (уплощенное дно). Основные орнаментальные мотивы таких сфероконусов: гроздья винограда, миндалевидные розетки, геометрические фигуры (треугольники, звездочки, капли). Могли дополнительно инкрустироваться стеклом или поливными вставками. В нашем случае сосуд украшен каплями и овальными медальонами с несколькими выпуклыми точками. Похожие сосуды найдены в Болгаре (Нуретдинова, 2011, с. 156-157; Виноградов, 1922, с. 111, табл. № 6, 72), Азаке (Масловский, 2006, с. 418, рис. 44, 12-13), в Ани и Двине (Джанполадян, 1982, рис. 2; 3; 5; 14; 15), Туркестане (Городцов, 1926, с. 156, рис. 4), Семиреченской области (Виноградов,
1922, с. 111, табл. № 6, 692), а также в Государственном Эрмитаже (сосуд куплен в Константинополе) (Ленц, 1904, с. 0102, табл. VII).

$\mathrm{B}$ эрмитажной коллекции имеется сосуд серо-желтого цвета эллипсоидной формы с расширенным в верхней трети туловом, со ступенчатым оформлением верхней части и штампованным растительным орнаментом (рис. 3: 2; Сар-606). Размеры: $\mathrm{H}-13$ см, D 9,2 см, Т - 1 см, һшл - 1,8 см, dшл - 3,2 см. На поверхности сфероконуса в придонной части наблюдаются следы копоти. На плечиках имеется пять «семечек» или «капель». Среди памятников на территории Румынии имеются экземпляры, которые сочетают в себе «сотовый» и подобный штампованный растительный орнамент. Однако в нашем случае мы имеем группу из 5 «семечек» или «капель». Сосуды с таким орнаментом найдены среди материалов Белгорода на Днестре (Кравченко, 1986, с. 62, рис. 24, 12), Маджара (Волков, 2004, с. 159, № 6), Исакча (Румыния) (Stănică, Szmoniewski, 2016, fig. 8). 

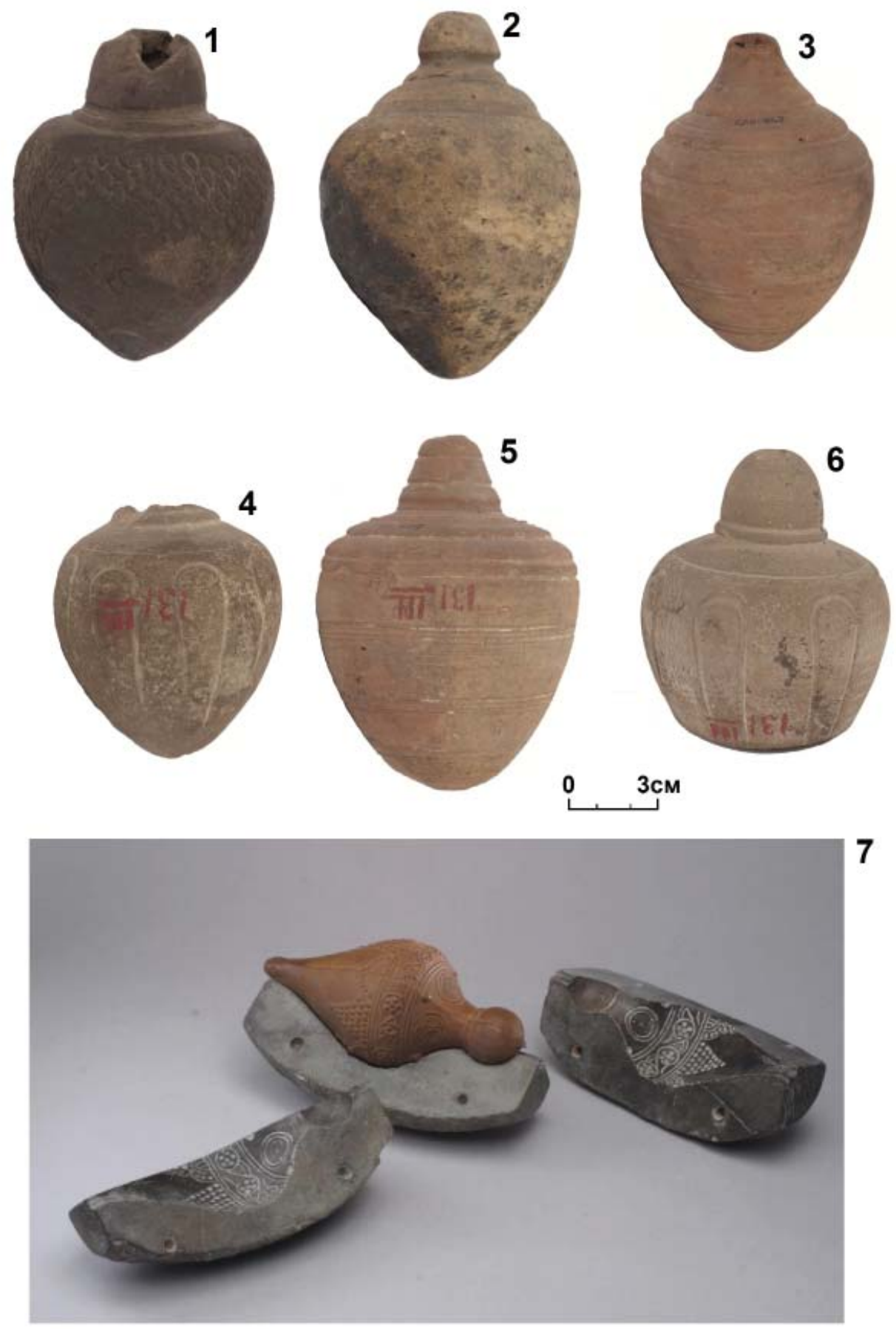

Рис. 3. Сфероконические сосуды из раскопок А.В. Терещенко, Государственный Эрмитаж. Фото из Государственного каталога Музейного фонда Российской Федерации

Fig. 3. Sphero-conical vessels from the excavations of A.V. Tereshchenko, State Hermitage.

Photo from the State Catalog of the Museum Fund of the Russian Federation

Любопытен сосуд желтого цвета эллипсоидной формы с расширенным в верхней трети туловом (рис. 1: 1), верхняя часть тулова украшена сиренами - фигурами с женскими головами и туловищем птиц. Сосуд происходит из раскопок А.В. Терещенко и хранится в Государственном Эрмитаже (Сар-303). Размеры: Н - 14,8 cм, D - 10,7 см. Сфероконические сосуды с антропоморфными изображениями редки (Fehervari, 2000, p. 209, № 272). Нам известен лишь один сосуд с личинами в Саратовском областном музее краеведения (Кротков, 1926, № 29; Михальченко, 1974 , с. 47 , рис. 1,2 ) и обломок сосуда с рельефным изображением всадника из Болгара в фондах ГИМ (Трубникова, 1940, с. 138). Оба сосуда происходят из старых поступлений и не имеют контекста.

В материалах раскопа 2-1964 г. Царевского городища (шт. 2, кв. 135) имеется обломок сфероконуса желтого цвета с нечетким штампованным орнаментом (рис. 4: 1). Фрагмент хранится в Археологическом музее КФУ 
Таблица 3. Сфероконусы красноглиняные с резными горизонтальными линиями Table 3. Red clay spheroconuses with carved horizontal lines

\begin{tabular}{|c|c|c|c|c|}
\hline № п/п & Шифр & Размеры, см & Иллюстрация & Примечание \\
\hline 1 & Сар-607 & $\mathrm{H}=12,1, \mathrm{D}=9, \mathrm{~T}=2$, дшл $=2,2$, дотв $=0,6$ & Рис. 3,3 & \\
\hline 2 & Сар-609 & $\mathrm{H}=12,6, \mathrm{D}=9,3, \mathrm{~T}=3$, дшл=2,7, дотв $=0,6$ & Рис. 3,5 & \\
\hline
\end{tabular}
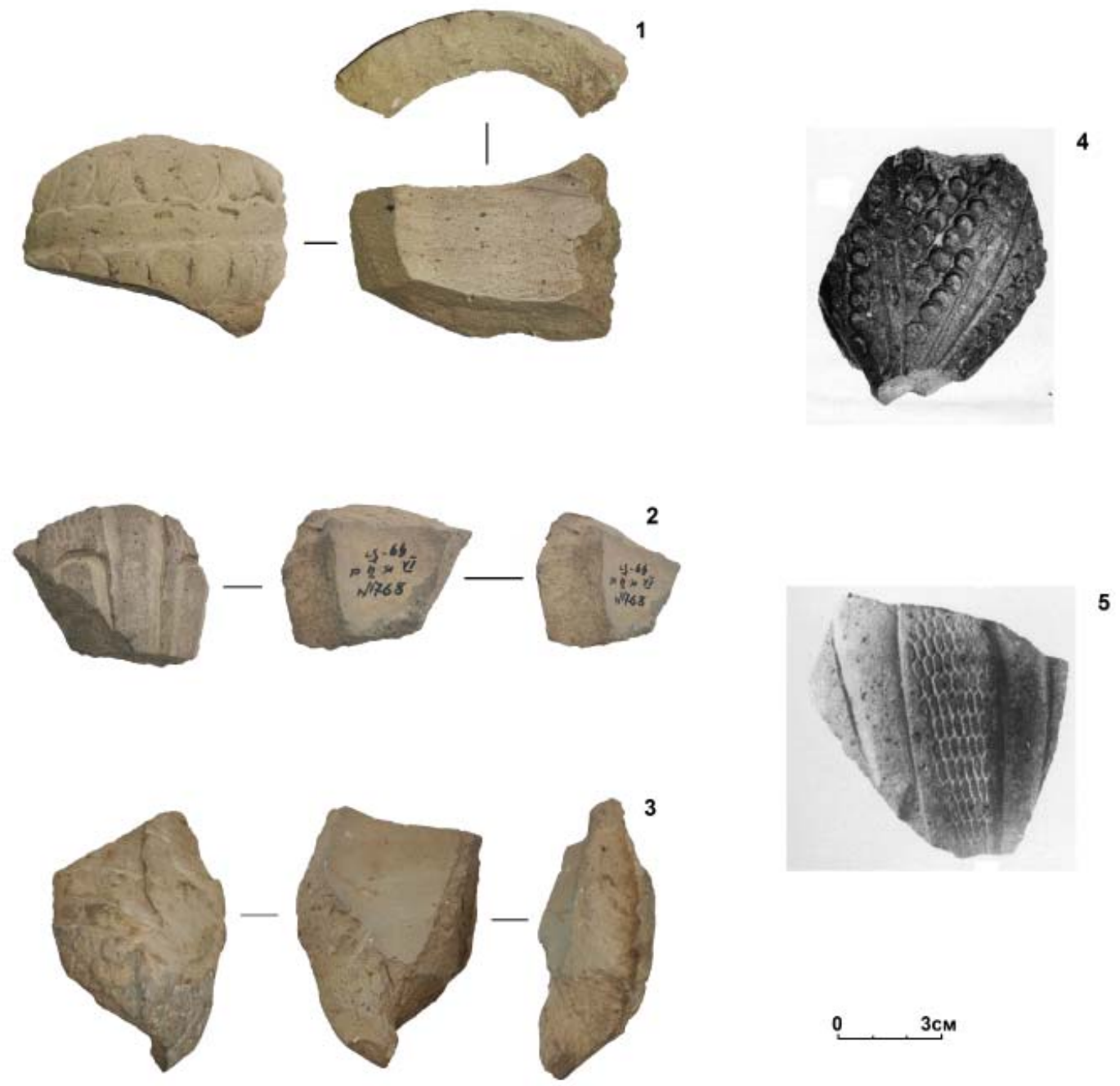

Рис. 4. Сфероконические сосуды из раскопок Г.А. Федорова-Давыдова: 1-3 - Археологический музей КФУ (фото автора), 4-5 - Волгоградский областной краеведческий музей (по: Федоров-Давыдов, 1964, рис. 83; Федоров-Давыдов, 1962, рис. 90)

Fig. 4. Sphero-conical vessels from the excavations of G.A. Fedorov-Davydov: 1-3 - Archaeological Museum of the KFU (photo by the author); 4-5 - Volgograd Regional Museum of Local Lore (after: Fedorov-Davydov, 1964, fig. 83; Fedorov-Davydov, 1962, fig. 90).

(АКУ-354/881). Размеры: 7,75×5,1×1,8 см. С внутренней стороны сфероконус был покрыт ангобом белого цвета.

Малочисленны на памятнике сфероконусы красного цвета - всего 4 экз. Все они хранятся в собрании Государственного Эрмитажа.

Двумя экземплярами представлены сосуды из красножгущейся глины сфероконической формы, с невыразительной шейкой (табл. 3). Они украшены парными резными горизон- тальными линиями по всей поверхности. Размеры: H - 12,1-12,6 см, D - 9-9,3 см, Т 2-3 см, dшл -2,2-2,7 cм, dотв-0,6 см. Аналогичные сосуды имеются в материалах Маджаpa (Волков, 2004, с. 159, № 8), Красноярского городища (Пигарев, 1994, с. 213, рис. 1,13).

Особо выделяется среди красных экземпляров крупный сосуд с залощенной поверхностью (Сар-388; рис. 2: 1). Размеры: Н 20,5 см, D - 13,5 см. В верхней части тулова 
имеется надпись. На Билярском городище найдено 13 экземпляров красных сосудов с округлым дном и больших размеров (толщина стенок не менее $3 \mathrm{~cm}$ ) во фрагментах (Нуретдинова, 2011, с. 154). Похожие сосуды известны на Самосдельском городище (Зиливинская и др., 2006, с. 33, рис. 7,1) и в городах Грузии (Valiulina, 2016, 267; Валиулина, 2005, с. 161).

Последний рассматриваемый сфероконус - красного цвета, со шляпковидной головкой и коническим дном (Сар-306, рис. 1: 3), поверхность которого украшена резными горизонтальными линиями и штампованным орнаментом (цветы, круги и т. д.). Размеры: Н $-15 \mathrm{~cm}, \mathrm{D}-11 \mathrm{~cm}$.

Особое внимание обращает на себя каменная разъемная форма для изготовления конусообразного сосудика, состоящая из 4 деталей. Ее размеры: $15,6 \times 8$ см. Она происходит из раскопок А.В. Терещенко и хранится в Государственном Эрмитаже (Инв. № САР-2, № в Госкаталоге: 5019627). Находки каменных форм для таких сосудов единичны: кроме царевского экземпляра нам известны находки из Софии (Станчева, 1961), Баальбека (Wulzinger et al., 1935, s. 77), Биляра (Джанполадян, 1958, с. 202). Из-за отсутствия находок сосудов, изготовленных в подобных формах, до сих пор нельзя точно сказать, из какого материала делали сосуды - металла, стекла или глины. Одно из последних исследований по изучению каменных форм было произведено болгарским археологом Дияном Йосифовым, который провел ряд экспериментов с помощью специально изготовленных каменных форм (Йосифов, 2015). В качестве материала для изготовления сосудов в формах была выбрана глина. Исследователь доказал возможность выполнения керамических сосудов в подобных формах. Однако было отмечено, что из-за маленького диаметра отверстия в таких калыпах возможно было делать только тонкостенные экземпляры, которые уступали в прочности обычным сфероконусам, сформованным на гончарном круге. Более вероятна версия изготовления в таких формах стеклянных изделий. В настоящее время известно о находках 16 таких сосудов, из них к золотоордынскому периоду относятся 5 (Алпаткина, 2011). По форме к нашей находке наиболее близок сфероконус из цветного стекла, который происходит из Гургана (Иран) и датируется XII-XIII вв. (Ettinghausen, 1965, plate XLVII, B).

На сегодняшний день нет свидетельств производства сфероконических сосудов на Царевском городище. Это, скорее всего, связано с тем, что памятник мало изучен - менее $1 \%$ от площади. Таким образом, дальнейшие исследования могут привести к новым открытиям. Однако уже можно констатировать, что находки сфероконусов, как на Царевском городище, так и в целом на нижневолжских памятниках, малочисленнее по сравнению со Средней Волгой. При этом в отличие от Болгара самой популярной формой на территории Нижней Волги были сосуды темносерого цвета с массивной головкой с валиком и коническим дном, с «сотовым» или «семечковидным» орнаментом. На данном этапе невозможно определить функциональное назначение царевских сфероконических сосудов из-за того, что большая часть не имеет контекста находок.

\section{ЛИТЕРАТУРА}

Абызова Е.Н. К вопросу о сфероконусах из Старого Орхея и Костешт // Археологические исследования в Молдавии в 1977-1978 гг. / Отв. ред. П.П. Бырня. Кишинев: Штиинца, 1982. С. 171-174.

Алпаткина Т.Г. Место стеклянных сфероконусов из Золотой Орды в общей классификации этого вида ремесленных изделий // Золотоордынская цивилизация. Вып. 4 / Отв. ред. И.М. Миргалеев. Казань: Фолиант; Институт истории им. Ш. Марджани АН РТ, 2011. С. 238-244.

Валиулина С.И. Стекло Волжской Булгарии (по материалам Билярского городища). Казань: КГУ им. В.И. Ульянова-Ленина, 2005. 280 с.

Виноградов 3.3. Сфероконические сосуды с узким горловым отверстием // Казанский музейный вестник. 1922. №2. С. 75-119.

Волков И.В. Химическая посуда в золотоордынских городах // 125 лет обществу археологии, истории и этнографии при Казанском университете. Проблемы историко-культурного развития ВолгоУральского региона. Археологические исследования: сб. научных докладов и сообщений. Ч. 1 / Под ред. С.И. Валиулиной. Казань: КГУ, 2004. С. 145-149.

Джанполадян Р.М. Сфероконические сосуды из Двина и Ани // СА. 1958. №1. С. 201-213.

Джанполадян Р.М. Сфероконические сосуды из Двина и Ани. Ереван: АН АрмССР, 1982. 50 с.

Зиливинская Э.Д., Васильев Д.В., Гречкина Т.Ю. Раскопки на городище Самосделка в астраханской области в 2000-2004 гг. // РА. 2006. №4. С. 24-35. 
Йосифов Д. За технологичните особености на каменните калъпи от София // Изследвания по българска средновековна археология / Отг. ред. П. Георгиев. Велико Търново: Фабер, 2007. С. 396-404.

Кравченко А.А. Средневековый Белгород на Днестре (конец XIII-XIV в.). Киев: Наукова думка, 1986. $186 \mathrm{c}$.

Кротков А.А. Сфероконические сосуды из Археологического Отдела Саратовского Государственного Областного музея // Труды Нижне-Волжского областного научного общества. Саратов, 1926. Вып. 35, ч. 1. С. 51-66.

Лени Э. О глиняных сосудах с коническим дном, находимых в пределах мусульманского востока // ЗВОРАО. Т. 15, Вып. 4. СПб.: Типография Императорской Академии Наук, 1904.. С. 101-115.

Масловский А.Н. Керамический комплекс Азака.Краткая характеристика // Историко-археологические исследования в г. Азове и на Нижнем Дону в 2004 году. Вып. 21. / Отв. ред. В.Я. Кияшко.Азов: Азовский музей-заповедник, 2006. С. 417-420.

Недашковский Л.Ф. Золотоордынский город Укек и его округа. М.: Восточная литература, 2000. $224 \mathrm{c}$.

Нуретдинова А.P. Сфероконические сосуды из старых собраний (XIX - начало XX вв.) музеев России. Казань: Изд-во Казан. ун-та, 2018. 108 c. URL: https://shelly.kpfu.ru/e-ksu/docs/F_1521378007/ Sferokonusy elektr..izdanie.pdf (дата обращения: 31.05.2021).

Нуретдинова А.P. Типология сферо-конических сосудов Волжской Булгарии // Урало-Поволжье в древности и средневековье. Материалы международной научной конференции V Халиковские чтения / Археология Евразийских степей. Вып. 11 / Отв. ред. Ф.Ш. Хузин. Казань: Институт истории АН РТ, 2011. C. $150-160$.

Пигарев E.M. Сфероконические сосуды из фондов Астраханского краеведческого музея-заповедника // Древности Волго-донских степей Вып. 4. / Ред. В.И. Мамонтов. Волгоград: Перемена, 1994. C. 210-215.

Полевой Л.Л. Городское гончарство Пруто-Днестровья в XIV в.: по материалам раскопок гончарного квартала на поселении Костешны. Кишинев: АН МолдССР, 1969. 211 С. 135-136.

Ртвеладзе Э.В. Сфероконические сосуды из Маджар // СА. 1974. №4. С. 280-284.

Самашев 3., Кузнеиова О., Плахов В. Керамика Сарайчика ( на казахском, русском и английском языках). Алматы: ZUR advertizing, 2008. 264 с

Скэнлон Дж.Т. Заметка о фатимидско-сельджукской торговле // Мусульманский мир / Отв. ред. В.В. Наумкин, М.Б. Пиотровский. М.: Наука, 1981. С. 282-291.

Станчева М. Каменни кальпи за сфероконуси от София // Археология. 1961. № 1. С. 22-27.

Древние памятники, отрываемые в Царевском уезде Саратовской губернии // ЖМВД. Спб., 1843. Ч. II. C. $426-430$.

Трубникова Н.В. Обломок сфероконического сосуда из Булгар // Сборник статей по археологии СССР. Труды ГИМ. Вып. ХІ / Под ред. Д.Н. Эдинга. М.: Изд-во ГИМ, 1940. С. 137-139.

Федоров-Давыдов Г.А. Научный отчет о раскопках 1962 г. на городище Сарай-Берке - столицы Золотой Орды / Архив ВОКМ. Д. 12.

Федоров-Давыдов Г.А. Научный отчет о раскопках на Царевском городище /Сарай-Берке/ в 1964 г. / Архив ВОКМ. Д. 17.

Федоров-Давыдов Г. А. Золотоордынские города Поволжья. М.: Изд. МГУ, 1994. 232 с.

Федоров-Давыдов Г.А. Раскопки Нового Сарая в 1959 - 1962 гг. // СА. 1964. № 1. С. 248-271.

Федоров-Давыдов Г.А., Вайнер И.С. Мухамадиев А.Г. Археологические исследования Царевского городища (Новый Сарай) // Поволжье в средние века / Отв. ред. А.П. Смирнов. М.: Наука, 1970. С. 68-171.

Feherwari G. Ceramics of the Islamic World inthe Tareg Rajab Museum. I.B. Tauris. London, New York, 2000. 399 p.

Ettinghausen R. The uses of sphero-conical vessels in the Muslim East // Journal of Near Eastern Studies, 1965. V. XXIV, № 3. P. 218-229.

Mănucu-Adameşteanu Gh. Din nou despre vasele sferoconice in lumina descoperirilor din nordul Dobrogei // Peuce: rapoarte, cataloage, studiişi note de istorieşi arheologie. 1984. Peuce IX (seria istorie). P. 363-374, 716-723.

Monchamp J. Sphero-conical Vessels from the Ayyubid Wall in Cairo: A Typology (11th-15th c.) // Journal of Islamic Archaeology. 2016. Vol. 3, № 2. P. 195-207. 
Nicolle D. Medieval Islamic Fire Grenades: Further Evidence from a Military Context // Journal of Islamic Archaeology. 2016. Vol. 3, № 2. P. 163-177.

Sharvit J. The sphero-conical vessels // IAA Report. Paneas. Vol. II. Small finds and other studies. 2007. № 38. P. 101-112.

Stănică A.-D., Szmoniewski B.S. The sphero-conical vessels from Lower Danube in the ligth of new discoveries from Isaccea, county Tulcea, Romania // Sprawozdania Archeologiczne. 2016. № 68. P. 327-344.

Valiulina S. Medieval workshop of an alchemist, Jeweller and Glassmaker in Bilyar (Middle Volga Region, Russian Federation) // Pamatky Archeologicke. 2016. Vol. 107. P. 237-278.

Vezzoli V. Sphero-conical Vessels from Baalbek: A Diverse and Challenging Collection // Journal of Islamic Archaeology. 2016. Vol. 3, № 2. P. 209-231.

Whitcomb D. A Note on "Grenades" as Fire-starter Flasks // Journal of Islamic Archaeology. 2016. Vol. 3, № 2. P. 179-186.

Wulzinger K., Wittek P., Sarre F. Tongranaten oder Handbrandgeschosse // Das islamische Milet. Berlin; Leipzig, 1935. S. 76-78.

\section{Информация об авторе:}

Нуретдинова Алсу Ренатовна, главный хранитель музейных предметов Археологического музея, Казанский (Приволжский) федеральный университет; Институт археологии им. А.Х. Халикова АН РТ (г. Казань, Россия); alsu.nuretdinova@rambler.ru

\section{REFERENCES}

Abyzova, E. N. 1982. In Byrnya, P. P. (ed.). Arkheologicheskie issledovaniia v Moldavii v 1977-1978 gg. (Archaeological Studies in Moldavia in 1977-1978). Kishinev: "Ştiinţa” Publ. (in Russian).

Alpatkina, T. G. 2011. In Mirgaleev, I. M. (ed.). Zolotoordynskaia tsivilizatsiia (The Golden Horde Civilization) 4. Kazan: "Foliant" Publ.; Institute of History named after Sh. Mardzhani, Tatarstan Academy of Sciences, 238-244 (in Russian).

Valiulina, S. I. 2005. Steklo Volzhskoi Bulgarii (po materialam Biliarskogo gorodishcha) (Glass of Volga Bulgaria: by materials of the Bilyar Fortified Settlement). Kazan: Kazan State University (in Russian).

Vinogradov, Z. Z. 1922. In Kazanskii museinyi vestnik (Kazan Museum Bulletin) 2. 75-119 (in Russian).

Volkov, I. V. 2004. In Valliulina, S. I. (ed.). 125 let obshhestvu arkheologii, istorii i etnografii pri Kazanskom universitete. Problemy istoriko-kul'turnogo razvitiya Volgo-Ural'skogo regiona. Arkheologicheskie issledovaniya: sb. nauchnykh dokladov i soobshheniy (The 125 th Anniversary of the Society of Archaeology, History and Ethnography under Kazan University. Issues of Historical and Cultural Development of the Volga-Ural Region. Archaeological Studies: Collection of Scientific Works and Reports) 1. Kazan:Kazan State University, 145-149 (in Russian).

Dzhanpoladyan, R. M. 1958. In Sovetskaia Arkheologiia (Soviet Archaeology) (1), 201-213 (in Russian).

Dzhanpoladyan, R. M. 1982. Sferokonicheskie sosudy iz Dvina i Ani (Spheroconical Vessels from Dvin and Ani). Erevan: Academy of Sciences of the Armenian SSR (in Russian).

Zilivinskaya, E. D., Vasiliev, D. V., Grechkina, T. Yu. 2006. In Rossiiskaia Arkheologiia (Russian Archaeology) (4), 24-35 (in Russian).

Iosifov, D. 2007. In Georgiev, P. (ed.). Izsledvaniia po srednovekovna arkheologiia (Studies on Bulgarian Medieval Archaeology). Veliko Tarnovo: "Faber" Publ., 396-404 (in Russian).

Kravchenko, A. A. 1986. Srednevekovyi Belgorod na Dnestre (konets XIII-XIV v.) (Medieval Belgorod on the Dniester (Late 13 $3^{\text {th }}-14^{\text {th }} \mathrm{cc}$.)). Kiev: "Naukova dumka" Publ. (in Russian).

Krotov, A. A. 1926. In Trudy Nizhne-Volzhskogo oblastnogo nauchnogo obshchestva (Proceedings of the Lower Volga Regional Scientific Society) 35 (1), 51-66 (in Russian).

Lents, E. O. 1904. In Zapiski Vostochnogo otdeleniia Imperatorskogo Russkogo arkheologicheskogo obshchestva (Proceedings of the Oriental Branch of the Imperial Russian Geographic Society). 15 (4). SaintPetersburg: Imperial Academy of Sciences Publ., 101-115 (in Russian).

Maslovskiy, A. N. 2006. In Kiiashko, V. Ya. (ed.). Istoriko-arkheologicheskie issledovaniia v Azove i na Nizhnem Donu (Historical and Archaeological Research in Azov and Lower Don Region) 21. Azov: Azov Historical-Archaeological and Palaeontological Museum-Reserve, 417-420 (in Russian).

Nedashkovskii, L. F. 2000. Zolotoordynskie goroda Nizhnego Povolzh'ia i ikh okruga (The Golden Horde City Ukek and its Suburbs). Moscow: "Vostochnaia Literatura" Publ. (in Russian).

Nuretdinova, A. P. Sferokonicheskie sosudy iz starykh sobranii (XIX - nachalo XX vv.) muzeev Rossii (Spheroconical Vessels from Old Collections (19th-early 20th cc.) of Russian Museums). Kazan: Kazan (Vorga 
Region) Federal University Available at: https://shelly.kpfu.ru/e-ksu/docs/F_1521378007/Sferokonusy_elektr..izdanie.pdf (accessed: 31.05.2021) (in Russian).

Nuretdinova, A. R. 2011. In Khuzin, F. Sh. (ed.). Uralo-Povolzh'e v drevnosti i srednevekov'e. V Khalikovskie chteniia (Ural and Volga Area in Antiquity and Middle Ages: $5^{\text {th }}$ Khalikov Readings). Series: Arkheologiia Evraziiskikh stepei (Archaeology of Eurasian Steppes) 11. Kazan: Institute of History, Tatarstan Academy of Sciences, 150-160 (in Russian).

Pigarev, E. M. 1994. In Mamontov, V. I. (ed.). Drevnosti Volgo-Donskikh stepei (Antiquities of Volga-Don Steppes) 4. Volgograd: "Peremena” Publ., 210-215 (in Russian).

Polevoi, L. L. 1969. Gorodskoe goncharstvo Pruto-Dnestrov'ia v XIV v. (Urban Pottery of the Prut-Dniester Region in the 14th c.) Kishinev: Academy of Sciences of the Moldova SSR (in Russian).

Ptveladze, E. V. 1974. In Sovetskaia Arkheologiia (Soviet Archaeology) (4), 280-284 (in Russian).

Samashev, Z., Kuznetsova, O., Plakhov, V. 2008. Keramika Saraychika (na kazakhskom, russkom i angliyskom yazykakh) (Ceramics of Saraichik hillfort). Almaty: "ZUR advertising” Publ. (in Kazakh, Russian and English).

Skalon, J. T. 1989. In Naumkin, V. V., Piotrovsky, M. B. (eds.). Musul'manskii mir (Muslim World). Moscow: "Nauka" Publ., 282-291 (in Russian).

Stancheva, M. 1961. In Arkheologiia (Archaeology) (1), 22-27 (in Bulgarian).

1843. Drevnie pamiatniki, otkryvaemye v Tsarevskom uezde Saratovskoi gubernii (Ancient Monuments Discovered in the Tsarevsky District of Saratov Governorate) In Zhurnal Ministerstva vnutrennikh del (Journal of the Ministry of Internal Affairs) (2). Saint Petersburg, 426-430 (in Russian).

Trubnikova, N. V. 1940. In Eding, D. N. (ed.). Sbornik statei po arkheologii SSSR (Collection of articles in the USSR Archaeology). Series: Proceedings of the State Historical Museum 11. Moscow: State Historical Museum, 137-139 (in Russian).

Fedorov-Davydov, G. A. Nauchnyi otchet o raskopkakh 1962 g. na gorodishche Sarai-Berke - stolitsy Zolotoi Ordy (Scientific Report on the Excavations of 1962 at Saray-Berke Settlement - the Capital of the Golden Horde) Archive of the Volgograd Regional Museum of Local Studies. Doisser 12 (in Russian).

Fedorov-Davydov, G. A. Nauchnyi otchet o raskopkakh na Tsarevskom gorodishche /Sarai-Berke/v 1964 g. (Scientific Report on the Excavations at Tsarevskoye Settlement / Saray-Berke / in 1964.) Archive of the Volgograd Regional Museum of Local Studies. Doisser 17 (in Russian).

Fedorov-Davydov, G. A. 1994. Zolotoordynskie goroda Povolzh'ia (Golden Horde Towns in the Volga Area). Moscow: Moscow State University (in Russian).

Fedorov-Davydov, G. A. 1964. In Sovetskaia Arkheologiia (Soviet Archaeology) (1), 248-271 (in Russian).

Fedorov-Davydov, G. A., Vainer, I. S., Mukhamadiev, A. G. 1970. In Smirnov, A. P. (ed.). Povolzh'e v srednie veka (Volga Region in the Middle Ages). Moscow: "Nauka" Publ., 68-171 (in Russian).

Feherwari, G. 2000. Ceramics of the Islamic World inthe Tareg Rajab Museum. I.B. Tauris. London, New York (in English).

Ettinghausen, R. 1965. In Journal of Near Eastern Studies. V. XXIV, № 3. 218-229 (in English).

Mănucu-Adameşteanu, Gh. 1984. In Peuce: rapoarte, cataloage, studiişi note de istorieşi arheologie. Peuce IX (seria istorie), 363-374, 716-723 (in Romanian).

Monchamp, J. 2016. In Journal of Islamic Archaeology.3 (2). 195-207 (in English).

Nicolle, D. 2016. In Journal of Islamic Archaeology.3 (2). 163-177 (in English).

Sharvit, J. 2007. In IAA Report. Paneas. Vol. II. Small finds and other studies. (38). P. 101-112.

Stănică, A.-D., Szmoniewski, B. S. 2016. In Sprawozdania Archeologiczne. (68), 327-344 (in English).

Valiulina, S. 2016. In Pamatky Archeologicke. (107), 237-278 (in English).

Vezzoli, V. 2016. In Journal of Islamic Archaeology. 3 (2). 209-231 (in English).

Whitcomb, D. 2016. In Journal of Islamic Archaeology. 3 (2). 179-186 (in English).

Wulzinger, K., Wittek, P., Sarre, F. 1935. In Das islamische Milet. Berlin; Leipzig, 76-78 (in German).

\section{About the Author:}

Nuretdinova Alsou R., Chief Curator of Museum Items of the Archaeological Museum, Kazan (Volga Region) Federal University. Kremlyovskaya St., 18, Kazan, 420000, the Republic of Tatarstan, Russian Federation; Institute of Archaeology named after A.Kh. Khalikov, Tatarstan Academy of Sciences. Butlerov St., 30, Kazan, 420012, Republic of Tatarstan, Russian Federation; alsu.nuretdinova@rambler.ru 